\title{
TACKLING LANGUAGE OBSTACLES IN CROSS- BORDER LITIGATION: THE EUROPEAN ORDER FOR PAYMENT AND THE EUROPEAN SMALL CLAIMS PROCEDURE APPROACH
}

\author{
Elena Alina Ontanu and Ekaterina Pannebakker*
}

\begin{abstract}
In cross-border litigation, language differences are one of the main obstacles preventing parties from taking action and defending their rights. The Regulations creating a European Order for Payment Procedure (EOP) and establishing a European Small Claims Procedure (ESCP) have introduced the first EU-wide procedures, the goals of which are to simplify, speed up, and reduce the costs of cross-border litigation; they also include an attempt to reduce language obstacles. However, the simplification they propose must not sacrifice parties' right of access to justice and fair trial. This paper addresses the question as to the way language obstacles in cross-border litigation are tackled by the EOP and the ESCP. It further seeks to determine the extent to which these instruments balance the aim to simplify the procedures by reducing language obstacles and the parties' right to a fair trial and access to justice.
\end{abstract}

Keywords: European Order for Payment, European Small Claims Procedure, harmonisation, cross-border litigation, language, translation, standard forms

\section{Introduction}

Cross-border litigation ${ }^{1}$ is more complex and often more expensive than pursuing a claim involving a domestic case. Within the European context, one of the reasons is the variety of official national languages in the European Union (EU). Cross-border litigation in the EU implies an exchange of documents and opinions between parties speaking different languages. Furthermore, for at least one of the parties, procedural requirements in a cross-border case emanate from another Member State and are established in a foreign language. The number of languages and the need for translation in cross-border litigation make it more difficult and expensive for parties to take action and to defend their rights.

In the EU, one of the ways to tackle the implications of cross-border litigation is the harmonisation of civil procedure. The harmonisation process received a major boost following the coming into force of the Treaty of Amsterdam in 1999 and the Tampere conclusions, ${ }^{2}$ and this process is set to be taken further with the Stockholm Programme. ${ }^{3}$ Based on Article 65 of the EC Treaty, incorporated now into Article 81 of the Treaty on the Functioning of the EU, the Community (now the EU) was empowered to adopt measures in the field of judicial cooperation in civil matters having crossborder implications. Procedural harmonisation was achieved mostly through primarily

Both authors are doctoral candidates in the Department of Private International and Comparative Law at the Erasmus School of Law, Erasmus University Rotterdam. The authors wish to thank Prof. Xandra Kramer for her constructive remarks, as well as Laura van Bochove and the peer reviewers for their comments on the first draft of this paper. The usual disclaimer applies.

Within the context of the European Order for Payment Procedure and the European Small Claims Procedure, this is defined as litigation where 'at least one of the parties is domiciled or habitually resident in a Member State other than the Member State of the court or tribunal seized' (Art. 3 EOP, Art. 3 ESCP).

See Tampere European Council 15 and 16 October 1999, Presidency Conclusions, <www.europarl. europa.eu/summits/tam_en.htm> (last visited 26 Apr. 2012).

The Stockholm Programme - An Open and Secure Europe Serving and Protecting the Citizens, European Council, OJ 2010 C115/1, <http://eur-lex.europa.eu/LexUriServ/LexUriServ.do?uri=OJ:C:2010 :115:0001:0038:en:PDF> (last visited 26 Apr. 2012). 
coordinating measures in the area of international jurisdiction and the cross-border service of documents (Brussels I Regulation, ${ }^{4}$ Service Regulation ${ }^{5}$ ), along with certain other cross-border issues. ${ }^{6}$

The Regulation creating a $\mathrm{EOP}^{7}$ and the Regulation establishing a ESCP, ${ }^{8}$ on which this article focuses, adopt another approach. These Regulations establish the first truly autonomous European civil procedures that are available as options in cross-border cases. The EOP and the ESCP seek to provide new procedures that are simpler and faster ${ }^{9}$ than the ordinary national procedures. This goal is pursued in the EOP and the ESCP inter alia by an attempt to reduce language obstacles in cross-border litigation, primarily by prescribing standard forms and by including particular rules relating to language.

However, the proposed simplifications must not sacrifice parties' right of access to justice and a fair trial. ${ }^{10}$ Hence, this simplification of civil procedure by the EOP and the ESCP raises several questions. Do the autonomous European procedures ensure that the party will be able to use his or her own language during litigation? If this is not the case, how do the EOP and the ESCP solve the question regarding choice of language to be used during proceedings?

This paper examines how language obstacles in cross-border litigation are tackled by the EOP and the ESCP, and whether these means are effective. It also seeks to determine the extent to which these instruments strike the balance between, on the one hand, the aim to simplify the procedures by reducing language obstacles and, on the other hand, the parties' right to a fair trial and proper access to justice.

To put these questions into context, we will first introduce briefly the main characteristics of the EOP and the ESCP, and address in general terms the requirements of a fair trial and access to justice. Thereafter, the analysis will focus on the language solutions established by the EOP and the ESCP, the standard forms' approach to language issues and their balance with the fair trial and access to justice, and, finally, possible alternative solutions to reduce language obstacles.

\section{Setting the Background: The EOP, the ESCP, and Procedural Rights}

\subsection{EOP and ESCP Characteristics and the Role of Standard Forms}

The EOP and ESCP Regulations ${ }^{11}$ apply to civil and commercial matters ${ }^{12}$ in crossborder cases ${ }^{13}$ in any court or tribunal. ${ }^{14}$ Cross-border cases within the context of these instruments are defined as those 'in which at least one of the parties is domiciled or habitually resident in a Member State other than the Member State of the court or tribunal seised'. ${ }^{15}$ The EOP and the ESCP are optional instruments as regards national

\footnotetext{
Reg. 44/2001, OJ 2001 L12/1.

Reg. 1348/2000, OJ 2000 L 160, replaced by Reg. 1393/2007, OJ 2007 L 324.

Such as, for example, Reg. 1206/2001 On Cooperation Between the Courts of the Member States in the Taking of Evidence in Civil or Commercial Matters, OJ 2001 L 174.

Reg. 1896/2006, OJ. 2006 L 399/1.

Reg. 861/2007, OJ 2007 L199/1.

See Art. 1(1) EOP, Art. 1(1) ESCP, Recital 7 ESCP. For the EOP, see also Green Paper on a European order for payment procedure and on measures to simplify and speed up small claims litigation, 20 December 2002, COM (2002) 746 final, at 10.

10 X.E. Kramer, 'The European Small Claims Procedure: Striking the Balance between Simplicity and Fairness in European Litigation', 16 Zeitschrift für Europäisches Privatrecht 355 (2008).

${ }_{11}$ For a more extensive overview on the EOP and ESCP characteristics, see also E. Storskrubb, Civil Procedure and EU Law. A Policy Area Uncovered (2008), at 203 and 220; A. Fiorini, 'Facilitating Crossborder Debt Recovery: The European Payment Order and Small Claims Regulations', 57 International and Comparative Law Quarterly 449 (2008).

${ }_{12}$ Except for matters enumerated within Art. 2(1) and (2) EOP and within Art. 2(1) and (2) ESCP.

3 Art. 3 EOP, Art. 3 ESCP.

Art. 2(1) EOP, Art. 2(1) ESCP.

See above n. 12.
} 
procedures. ${ }^{16}$ The EOP applies to uncontested monetary claims, ${ }^{17}$ while the ESCP applies to small claims not exceeding $€ 2,000$, regardless of whether they are contested. ${ }^{18},{ }^{19}$ The procedures are conducted entirely by means of standard written forms (Annex IVII of the $\mathrm{EOP}^{20}$ and Annex I-IV of the $\mathrm{ESCP}^{21}$ ). The claim/application forms contain information on the parties and their representatives; on the ground of jurisdiction; on the cross-border nature of the claim; on the cause of action (including a description of the circumstances invoked as basis of the claim); on the amount of the claim (including costs, contractual penalties, and interest if applicable); and on the description of the evidence supporting the claim. In addition, the ESCP requires that the parties submit any relevant documents supporting their statements. The opposition form in the EOP and the answer form within the ESCP are drafted according to the type of procedure established by the Regulations (single sided for the EOP and adversarial for the ESCP), and include information on the parties. The ESCP answer form also includes information on the claim; on supporting evidence; on requesting an oral hearing; on claiming costs of proceedings; and on the possibility of filing a counterclaim together with the response. Generally, the court issues its judgement based on the standard forms submitted by the parties. A court hearing might be organised only in a ESCP if the court considers that a hearing is necessary for it to reach a conclusion or if the parties so request. ${ }^{22}$

The taking of evidence and the holding of court hearings are possible within a ESCP; however, in view of the costs incurred, the court has to decide that these actions are really necessary for issuing the judgment. Representation by a lawyer or legal professional is not mandatory in any of these Regulations. Practical assistance in filling in the forms must be provided to the parties by the Member States in the case of a ESCP. ${ }^{23}$

The enforcement of EOP and ESCP judgments is governed by the law of the Member State where enforcement is to take place, similarly to any national judgement issued by a court in that country. The party seeking to obtain enforcement of a decision issued in another Member State will be required to provide a copy of the judgement satisfying the conditions to establish its authenticity. The decision must also be translated into the official language of the Member State or into another language that the Member State of enforcement has deemed acceptable. Possibilities of refusal, of stay, and of limitation of enforcement are established limitedly by EOP and ESCP Regulations.

On the whole, procedures relying on standard forms, limiting the necessity and possibility of court hearings, have a potential to reduce the need of translation, thus reducing language obstacles for the parties. In reality, however, the situation is more complex, and our analysis will tackle these points in Section 3.

\subsection{Fair Trial and Access to Justice Procedural Guarantees}

The simplification of court proceedings for parties litigating in cross-border cases should not result in breaches of procedural guarantees recognised by the European

\footnotetext{
16 The decisions issued according to the EOP and the ESCP are automatically recognised in all Member States, except Denmark, without any additional declaration of enforceability (exequatur for these decisions is abolished and is not required) (Art. 19 EOP, Art. 20 ESCP).

17 Art. 1 EOP.

1 Art. 1 ESCP

19 In uncontested monetary claims below $€ 2,000$, the claimant can choose between using either of these Regulations.

${ }^{20}$ Form A - Application for a European order for payment (Ann. I), Form B - Request to the claimant to complete and/or rectify an application for a European Order for Payment (Ann. II), Form C - Proposal to the claimant to modify an application for a European Order for Payment (Ann. III), Form D - Decision to reject the application for a European Order for Payment (Ann. IV), Form E - European Order for Payment (Ann. V), Form F - Opposition to a European Order for Payment (Ann. VI), Form G - Declaration of enforceability (Ann. VII) attached to the EOP Regulation.

${ }_{21}$ Form A - Claim Form (Ann. I), Form B - Request by the Court or Tribunal to Complete and/or Rectify the Claim Form (Ann. II), Form C - Answer Form (Ann. III), Form D - Certificate concerning a Judgment in the European Small Claims Procedure (Ann. IV) attached to the ESCP Regulation.

22 Art. 5(1) ESCP.

23 Art. 11 ESCP.
} 
Convention of Human Rights and Fundamental Freedoms ('ECHR') and the Charter of Fundamental Rights of the European Union ('Charter'). It should be noted that the right for a party to be informed 'in its own language' is directly provided by the ECHR only for the accused when a criminal offence is involved (Article 6(3a) ECHR). In civil litigation, the language used in the proceedings is related to the concepts of fair trial, particularly to the concepts of equality of arms and access to justice.

The requirement of fair trial is provided by Article 6(1) ECHR, and is part of the Member States law. The concept of fair trial is not defined within the EU treaties, the secondary legislation, or the Charter. The case law of the European Court of Human Rights ('ECtHR') interpreting the 'right to fair trial' as well as Article 47 of the Charter point inter alia to the following rights: ${ }^{24}$ access to justice, ${ }^{25}$ fair public hearing, ${ }^{26}$ the right to adversarial proceedings and equality of arms, and an effective enforcement ${ }^{27}$ of the decision issued by the court. These guarantees secure that a party in civil litigation is able to represent his or her legal position adequately and to benefit from an equal treatment. ${ }^{28}$

'Equality of arms' requires that a party should not be placed in a position of 'substantive disadvantage' compared to the other party. ${ }^{29}$ This last element of the right to a fair trial seems to be the most relevant for the discussion of language obstacles. Crossborder litigation usually implies a necessity for one of the parties to deal with foreign rules of procedure established in a foreign language. This language could be familiar to the other party.

Equality of arms would imply that both parties are equally informed about the procedure and the procedural consequences of their acts. Furthermore, if one party is unable to understand a part of the documents in proceedings, this may result in a serious disadvantage for that party. An opportunity should therefore be created for the party to assess the relevance of these documents during proceedings. Access to justice is framed within the provisions of Articles 6 and 13 of the ECHR and Article 47 of the Charter. ${ }^{30}$ The initial meaning of access to justice was encompassed between the aim of reducing litigation barriers resulting from the costs, the duration, and the difficulties of communication in judicial procedure. ${ }^{31}$ With its incorporation into the text of the Treaty of Amsterdam (Articles 61 and 65, now Article 81 following the Treaty of Lisbon), access to justice is perceived from two different perspectives: first, from the human rights dimension within the right to a fair trial, and second, as one of the elements of the principle of rule of law, ${ }^{32}$ because the rule of law is not conceivable without a real possibility of access to justice. ${ }^{33}$ From the case law of the ECtHR, access to justice points towards an access to court in law as well as in fact. This means that effective access to justice is not limited to the existence of a competent court and a

\footnotetext{
24 For the guarantees that Art. 6(1) of the ECHR prescribes, see N.H. Andrews, 'A Modern Procedural Synthesis. The American Law Institute and UNIDROIT's Principles and Rules of Transnational Civil Procedure', 17 Tijdschrift voor Civiele Rechtspleging 54 (2009).

25 Golder v. United Kingdom, ECHR (1975) 4451/70, EHRR (1975) Series A, No. 18, 525.

26 Case C-276/01, Steffensen (2003), ECR I-3735.

27 Hornsby v. Greece, ECHR (1997) Reports 1998-II 18357/91: The 'right to a court... would be illusory if a Contracting State's domestic legal system allowed a final, binding judicial decision to remain inoperative to the detriment of one party'. See on this decision C.H. van Rhee and A. Uzelac, 'Introduction', in C.H. van Rhee and A. Uzelac (eds.), Access to Justice and the Judiciary: Towards New European Standards of Affordability, Quality and Efficiency of Civil Adjudication (2009) 1, at 2.

28 C. Grabenwarter, 'Fundamental Judicial and Procedural Rights', in D. Ehlers (ed.), European Fundamental Rights and Freedoms (2007) 151, at 164.

29 Id.

30 X.E. Kramer, 'Abolition of Exequatur Under the Brussels I Regulation: Effecting and Protecting Rights in the European Judicial Area', 29 Nederlands Internationaal Privaatrecht 639 (2011).

31 B. Hess, 'EU Trends in Access to Justice', in C.H. van Rhee and A. Uzelac (eds.), Civil Justice Between Efficiency and Quality: From Ius Commune to the CEPEJ (2008) 189, at 189.

32 B. Gavrilović, 'Access to Justice and Civil Legal Aid in the European Union', in S. Pennicino (ed.), European Union and Legal Reform 2009 (2010) 23, at 24. See Case 190/84, Parti écologiste 'Les Verts'v. European Parliament, [1988] ECR 1017.

${ }_{33}$ Golder v. United Kingdom, ECHR (1975) Series A, No. 18, 41. See also F.G. Jacobs, 'Access to Justice as a Fundamental Right in European Law', in G.C. Rodríguez Iglesias and F. Schockweiler (eds.), Mélanges en Hommage à Fernand Schockweiler (1999) 197, at 200.
} 
formal entitlement to institute proceedings - it also implies an effective possibility ${ }^{34}$ for the parties to bring an action before the court in a particular case in terms of procedural requirements, time frame, and costs, without being hindered unreasonably by practical impediments. The right of access to justice therefore requires clear, simple access to legal provisions for parties to easily discern and choose the remedies as well as the court they have to address in a particular case. ${ }^{35}$ To this might be added the question of the language in which a court should be addressed, and the language in which parties should or might be addressed.

These aspects of parties' procedural rights are relevant for analysing the EOP and ESCP approach to language obstacles.

\section{The EOP and the ESCP: A New Approach to Language Obstacles}

\subsection{Information and Assistance in a Familiar Language}

The EOP and ESCP Regulations' recitals acknowledge the need to ensure access to justice, and the ESCP mentions expressly that it seeks to promote fundamental rights (Recital 9).

Access to court is to be facilitated in the EOP and the ESCP by the use of simple standard forms published as an integral part of the Regulations in all 23 official languages of the EU. These forms are available electronically on the e-Justice ${ }^{36}$ portal of the European Commission, on the Judicial Atlas ${ }^{37}$ and on the site of the European Judicial Network in civil and commercial matters. ${ }^{38}$ On the basis of Articles 28 and 29 EOP and of Articles 24 and 25 ESCP, at the national level, Member States should provide the general public with information about the procedures, related costs, accepted means of communication, availability of an appeal within the ESCP, courts having jurisdiction, languages accepted for enforcement purposes, and competent authorities for enforcement of the EOP and ESCP decisions. In the application of these provisions, the websites of consumer organisations, courts and/or official judiciary should contain information on these European instruments and provide access to the standard forms. ${ }^{39}$ This seems to be the case in practice, with the EOP and ESCP forms available on these sites. Therefore, any party filing or receiving a EOP or a ESCP claim is provided with a possibility to read in his or her own language what information is required or served with. The ESCP claim form (Form A) highlights expressly the availability of forms in all official EU languages on the European Judicial Atlas. This might be of help for filling in a form in a different language. Form A also refers to jurisdiction rules and to a glossary of legal terms that may be employed by the claimant. ${ }^{40}$ Such an explanation addresses some of the language difficulties that parties may experience when filling in the standard forms in a foreign language. It is a helpful contribution in guiding and

34 Airey v. Ireland, ECHR (1979) Series A, No. 32. See also M. Cappelletti, B. Garth, 'Access to Justice: The Worldwide Movement to Make Rights Effective. A General Report', Access to Justice. A world Survey (1978) 1, at 8-9.

35 E. Schmidt-Assmann and L. Harings, 'Access to Justice and Fundamental Rights', 9 Revue Européenne de Droit Public 529 (1997).

36 Section 4 of this article provides more information on the e-Justice portal, <www.e-justice.europa.eu $>$ (last visited 22 Jun. 2012).

$37<$ http://ec.europa.eu/justice_home/judicialatlascivil/html/index_en.htm> (last visited 22 Jun. 2012).

$38<$ http://ec.europa.eu/civiljustice/simplif_accelerat_procedures/simplif_accelerat_procedures_ec_ en.htm> (last visited 22 Jun. 2012).

39 For example, in the Netherlands, this is the Rechtspraak website <www.rechtspraak.nl/Naar-derechter/Formulieren/Pages/Europese-procedure-geringe-vorderingen.aspx $>$ (last visited 22 Jun. 2012); in France, this is the website of the European Consumer Centre <www.europe-consommateurs.eu/fr/ vos-droits/exercer-ses-droits/acces-a-la-justice/procedures-europeennes-simplifiees/> (last visited 22 Jun. 2012) and the Ministry of Justice website <www.justice.gouv.fr/europe-et-international-10045/textes-etreformes-10314/decret-relatif-a-la-procedure-europeenne-dinjonction-de-payer-17324.html $>$ (last visited 22 Jun. 2012).

${ }_{40}$ See the punctual information and guidelines in Ann. I and III of the ESCP Regulation regarding the claim and answer form. 
assisting the parties. In fact, the need of legal terminology explanation and assistance in understanding the requirements of the standard forms has proven to be necessary in practice. A pilot study undertaken by the European Consumer Centre (Centre Européen de la Consommation Kehl/Strasbourg) in France on French and German consumers filing EOP or ESCP claims revealed that laypersons have difficulties in understanding standard legal language. The information demanded by the foreign court is in certain cases highly technical, and parties are not able to manage the case without legal assistance. ${ }^{41}$ Moreover, the information provided to potential parties is not sufficient for a layperson to handle the cross-border procedures. ${ }^{42}$

The information contained on the above-mentioned European websites is indeed very general. Even more worrying is that certain specific procedural details are not provided clearly: namely, they are either outdated or inaccurate. For instance, the Judicial Atlas contains information submitted by the Member States to the Commission, in application of the requirements in Article 29(1)(d) EOP and Article 25(1)(d), referring to the language(s) accepted by Member States for enforcement purposes. However, no reference is made to the language in which the claim and answer forms have to be filed with the competent court. The e-Justice portal provides erroneous information on the languages in which the standard forms can be submitted to the courts. For example, according to the Judicial Atlas, for the purpose of enforcement, France accepts forms in French, English, German, Spanish, and Italian. ${ }^{43}$ The e-Justice portal mentions that France accepts these languages for all forms, including claim and answer forms in the course of proceedings; however, this is not accurate. ${ }^{44}$ According to the same e-Justice website, Ireland is supposed to accept forms only in English. This is not correct either, because Ireland is a bilingual country, and procedures in court can be conducted not only in English but also in Irish (Gaelic). ${ }^{45}$ This state of affairs is alarming, as equality of arms supposes that sufficient and accurate information is provided to parties. Furthermore, these websites are meant to provide assistance and information to the parties rather than to create more confusion.

Another aspect worth mentioning here is that in situations where one approaches the e-Justice portal in his or her own language, but needs to file a form in another country, the form remains in the party's own language, and the site does not provide further instructions regarding language. This may create confusion for the parties and result in additional costs and procedural delays due to the court's request for rectification of the submitted form.

The ESCP Regulation contains a special provision on practical legal assistance to be made available to the parties filling in the form (Article 11). Thus, Member States have to make this assistance available under the national system. ${ }^{46}$ In practice, a body or an institution providing assistance at the national level might not always be easy to identify for a potential claimant or defendant. In the Netherlands, for example, advice on the ESCP procedure is not institutionalised, and no institution has been officially assigned for this task. In practice, the assistance is carried out by the Dutch European Consumer Centre (ECC-NL), ${ }^{47}$ which is part of the Juridisch Loket. However, no information on the ESCP and assistance is available on its website. Upon the request of the interested

\footnotetext{
${ }_{41}$ 'Procédure de Règlement des Petits Litiges et Injonction de Payer Européenne. Des Procédures Simplifiées Pas Si Simples dans la Pratique' issued by the Centre Européen de la Consommation - Zentrum für Europäischen Verbraucherschutz e.V., at 5 <www.europe-consommateurs.eu/fileadmin/user_upload/ eu-consommateurs/PDFs/publications/etudes_et_rapports/4.4.3_procedure_de_reglement_des_petits_ litiges.pdf $>$ (last visited 22 Jun. 2012).

${ }^{42}$ See for this purpose also the results presented in the 'Procédure de Règlement des Petits Litiges et Injonction de Payer Européenne', above n. 41.

${ }_{43}$ Acceptance of such a wide range of languages is exceptional, and is questionable in view of the general language capabilities of enforcement officers and courts.

44 S. Guinchard (dir.), Droit et Pratique de la Procédure Civile (2009), at 552.

45 Art. 8 of the Constitution of Ireland, <www.constitution.ie/reports/ConstitutionofIreland.pdf $>$ (last visited 04 Jul. 2012).

46 For example, Ireland specifically provides in Art. 4(1) of Statutory Instruments No. 583/2008 published in the Iris Oifigiuil (Irish official journal publishing sources of law) of 6 January 2009 that the claimant may contact the court office if needing assistance in completing the claim form.

$47<$ www.eccnl.eu/> (last visited 06 Jun. 2012).
} 
party, ECC-NL provides a standard set of information, offers assistance in filling in the forms, and arranges translation of the claim form ${ }^{48}$ if necessary. ${ }^{49}$ In the Netherlands, courts and court registries do not provide this assistance to the public; usually, they refer the parties to the Judicial Atlas and to the Juridisch Loket. Some courts send the forms to the potential claimant. However, in order not to be held liable if problems arise during procedures, the courts and their registrars are generally not forthcoming in terms of giving assistance. ${ }^{50}$

The EOP Regulation approaches the question of practical assistance differently. Due to the one-sided nature of the EOP procedure, Member States are not obliged to provide assistance or information on the EOP to parties or potential parties. A EOP becomes enforceable only if no opposition to claim is lodged by the defendant. If an opposition from the defendant is lodged, the case must be handled according to ordinary national procedural rules (Article 16(2) in conjunction with Article 17 EOP). From this moment, national procedural rules, including the rules on language of procedure, will apply.

The EOP and ESCP provisions seek to create a balance between parties' rights and the purpose of these procedures. A possibility for parties to read standard forms in any EU official language, provided by both procedures, and a possibility of receiving legal assistance in a party's own language, provided by ESCP, are the solutions geared to lessen the need of professional translation. The two European procedures are a step forward in facilitating an easier access to justice and are a premise in lessening the burden of translation costs. Nonetheless, in practice there are still barriers to overcome when it comes to available information and assistance in filling in a form in the national language or in a foreign language. More transparency in the organisation of the assistance and a more careful selection and presentation of information on the procedures are desirable.

\subsection{Language of the Forms and Other Documents}

In order to analyse the language requirements within the EOP and ESCP standard forms, a distinction should be made between several concepts: namely, language of procedure, language of supporting documents (that may be the language of documents to be served or the language of documents to be just dispatched), and language of the document to be enforced. These concepts differ because they refer to different languages within the same proceedings. Neither the EOP nor the ESCP mention the distinction explicitly. The EOP and the ESCP use the term language of the form, but in fact the language of the form can turn out to be one of the four mentioned above, depending on who is sending the form to whom and for which purpose.

\subsubsection{EOP Approach}

The text of the EOP Regulation does not include specific provisions on language of procedure or language of documents to be served on the other party during the procedure. The application form (Form A), ${ }^{51}$ the form of request to complete and/or rectify the application form (Form B), ${ }^{52}$ and the Guidelines accompanying the application form ${ }^{53}$ contain indications for the parties with respect to the language in which these forms must be filled in. This is 'the language or one of the languages accepted by the court to be seized'. Further clarifications on the possible language of the court or the language

\footnotetext{
48 In practice, the ECC-NL collaborates with the other ECC within the Member States to translate the necessary form in the language of procedure.

49 See on the findings from practice X.E. Kramer and E.A. Ontanu, 'Cross-border Small Claims Litigation. The Dutch Perspective: Guarded Optimism and Pragmatism', part of The Future of Small Claims Litigation project, forthcoming publication, Section 5.1. 
in which service needs to be carried out are not provided by the EOP. Reference to Brussels I Regulation in the Guidelines to the application form may only provide an implicit guidance regarding the language ${ }^{54}$ In principle, the aforementioned EOP provisions refer to the language of procedure. This is the language of the court: namely, the language in which the parties should address the court, and in which the court issues a decision. Most of the time, this is the official language of the Member State. In multilingual states, the language of procedure is one of the official languages; the concrete choice of national language in the procedure is to be determined according to the national rules. ${ }^{55}$

Any claim form filled in using the wrong language may be rectified according to Article 9 of the EOP Regulation; the competent court would then indicate the language in which the form has to be completed and re-sent. A possibility to rectify the form is an important safeguard for the claimant, but might result in the need to translate the form into the language of procedure. In principle, the volume of information that should be translated in forms is reduced to a minimum because the forms contain closed questions and use a system of codes to answer most of these questions (we examine these in more detail in Section 3.3 of this paper). However, the description of evidence and additional statements by the claimant (points 10 and 11 in Form A) are open questions, and will therefore need translation. Nonetheless, the need of professional translation is limited only to a description of the evidence on which the claim is based. This evidence does not need to be produced in full or translated if it is not in the language of procedure.

After the claimant sends Form A to the court, the court has to serve a copy of the application form (Form A) together with the EOP (Form E) to the defendant. The court serves its decision according to Articles 13 and 14 in the EOP, which establish service rules for these procedures, apart from the ones in the Service Regulation. Since the EOP does not contain any norms on the language of documents to be served, the only European harmonised instruments containing rules on language of documents to be served is the Service Regulation. Therefore, the Service Regulation provisions on languages ${ }^{56}$ are applicable when documents need to be served in a EOP. ${ }^{57}$ According to the provisions of Article 8(1) of the Service Regulation, the defendant may refuse a EOP and the copy of the application form if these are "not written in or accompanied by a translation' into a language that the defendant understands or in the official language of the Member State where service is to be effected. This means that for EOP, the documents to be served should either be established in the language that the defendant understands or in an official language of the Member State where the service should be made, or translated into one of these languages. Indeed, in almost all cases, the same form should be established in two languages simultaneously: the language of procedure (to communicate with the court) and the language of the other party (in order to be served to the other party).

If a translation is needed, the costs should be borne by the claimant (on the basis of Article 5(2) of the Service Regulation). These costs are procedural ones. A possibility to include costs ('court fees' and 'other costs') is provided by the EOP application form. However, a party does not always know in advance whether the defendant will refuse a document, and to what extent a translation will be needed. Defining these costs in advance can therefore become impossible in practice. Moreover, the application form does not refer to the translation costs. Taking into account that translation is often needed in cross-border cases, and that the EOP is designed for such cases, an additional field regarding eventual translation costs would be appropriate in the application form.

\footnotetext{
54 Reasoning in terms of user friendliness, reference to Brussels I represents a guidance for a legal specialist but not for a layperson.

${ }_{55}$ See 'Important information' in Guidelines for Filling in the Application form, Ann. I EOP.

56 See Arts. 5 and 8 Service Regulation. According to Art. 27 EOP, establishing the relationship between the EOP Regulation and Service Regulation, the EOP Regulation does not affect the application of the Service Regulation in the Member States.

57 On certain language-related issues in the Service Regulation, see C. Vanheukelen, 'Taalproblematiek bij de betekening aan een buitenlandse bestemmeling', in M. Pertegás et al. (eds.), Betekenen en uitvoeren over de grenzen heen (2008) 49.
} 
Furthermore, the defendant should be informed in writing of the possibility to refuse or to send back the documents that are not in a language that he or she understands, or are not in the official language (or one of the official languages) of the place of service. ${ }^{58}$ This provision should be understood in the light of the equality of arms requirement.

Finally, Form G is used to enforce the European Order for Payment. This form needs to be translated into the language accepted by the Member State of enforcement ${ }^{59}$ if the language of procedure (and therefore the language in which the court issues Form G) is not in a language that is accepted by the Member State of enforcement. Including straightforward information in Form $G$ about the necessity to translate would be an asset. At the same time, costs for the translation of Form $G$ for execution cannot be included in advance in Form A. In fact, the defendant might execute the decision or oppose the application, and subsequently not be held liable at all. Hence, this expense might never occur.

The first evaluation of the EOP application confirms that lack of clarity on language provisions causes problems in practice. As revealed by the European Consumer CentreFrance (ECC France) research project, language obstacles in handling and responding to the standard forms are one of the main difficulties faced by parties. ${ }^{60}$ Consumers have serious difficulties in understanding the requests of foreign courts for additional information or rectifying the claim form in EOP procedures. Legal assistance and translation are necessary throughout the case. ${ }^{61}$

The EOP approach diminishes the volume of information to be translated by not relying on any additional procedural documents other than the standard forms in order to substantiate or oppose the procedure. However, translation remains necessary in order to fill in the claim form, to serve the EOP on the defendant, to lodge an opposition, and, through enforcement, to guarantee a defendant's access to justice and the right to a fair trial. De lege ferenda, we are of the opinion that clear language provisions with respect to service and procedural language should be considered for the EOP review. It may be useful if the forms were to contain a reference for the parties regarding the language of the procedure: that is, the language of communication with the court (as per EOP in combination with national rules of a concrete Member State). It is also desirable that Form A inform the claimant that his or her communication with the defendant be undertaken in the language of the defendant (a EOP in conjunction with Service Regulation and national rules of the concrete Member State on language). In practical terms, this means that the same forms should be used twice in different languages. Furthermore, the form should make explicit the need to include the costs of translating Form A in the field 'costs' in the application form. Form F (opposition to a EOP) should inform the defendant that his or her communication with the court should be carried out in the language of procedure. Finally, it should be made transparent that translation will always be needed for enforcement of the EOP (Form G) in another Member State. This algorithm with different outcomes depending on the addressee and his or her language seems difficult to implement in a paper-based form; it can be more easily envisaged in a dynamic form in electronic format. ${ }^{62}$

\subsubsection{ESCP Approach}

In contrast to the EOP, the ESCP Regulation contains in its Article 6 specific provisions on language of procedure and language of documents to be served on or dispatched to the other party during the procedure.

Points (1) and (2) of Article 6 provide requirements for the language of procedure. Documents used by the parties in communication with the court ("the claim form, the

$58 \quad$ Art. 8(1) Service Regulation.

59 One of the languages reported by the Member States and made public though the official portals that we touched upon in Section 3.1.

60 'Procédure de Règlement des Petits Litiges et Injonction de Payer Européenne', above n. 41, at 6.

${ }_{61}$ As revealed by this study, the French consumers had difficulties in understanding the request of the German Court, the legal terminology, and the language.

62 For perspectives on technical solutions, see Section 4. 
response, any counterclaim, any response to counterclaim and any description of relevant supporting documents') must be filled in 'in the language or one of the languages of the court or tribunal'. In addition to Article 6(1) and (2), the claim form (Form A) ${ }^{63}$ and the answer form (Form C) ${ }^{64}$ remind parties that these forms should be filled in in the language of the court/tribunal'. Therefore, the two forms refer parties to the language of procedure. However, neither Articles 6(1) and (2) nor the forms clarify which concrete language is the language of the court. The Reference to the Brussels I Regulation in the Form A guideline on jurisdiction contains an implicit guidance regarding the language for the parties. ${ }^{65}$ In most cases, the language of procedure is the official language of the Member State. In Member States having more than one official language, the concrete choice of procedure language is to be determined according to the national procedural rules on languages ${ }^{66}{ }^{6}$ Furthermore, it appears useful that the forms and/or EU websites provide more concrete information on the language in which the court accepts the documents. The reference in Form A to Brussels I and the European Judicial Atlas website on the jurisdiction provide only an implicit suggestion relating to the language of procedure. It is not a clear reference to the language to be used by the party when filing a claim with the court, and laypersons can be easily confused. In fact, a ESCP requires Member States to notify the Commission only about the languages that Member States accept for enforcement purposes. ${ }^{67}$ As mentioned above in Section 3.1, in certain cases the languages accepted for enforcement are not necessarily the language in which the procedure may be conducted in courts. It is desirable, therefore, that ESCP forms provide a reference to the concrete language of the procedure to be used by the party in communication with the court, depending on the concrete court where the party intends to file the claim. This reference might help limit confusion resulting from language issues and reduce cases where the court needs to ask for rectification of information (using Form B).

Language obstacles resulting from the requirement of filling in the forms in the 'language of the court' are to a certain extent eliminated by the use of automatic translation applications of forms. ${ }^{68}$ Many questions in the forms are closed questions. Translation remains necessary only for the descriptive questions and additional evidence documents if deemed necessary by the court. Furthermore, Article 6(2) establishes that the court may require a translation of a document 'only if the translation appears to be necessary for giving the judgement'. This provision can contribute to reducing language obstacles and translation requirements. However, it may prove difficult to decide on the role of a document submitted to the court in a language the judge does not understand. The description of evidence should, in principle, provide the judge with some guidance; in practice, however, this might not be of substantial help unless the information is presented in a coherent manner. In fact, in completing the forms, parties not benefitting from legal assistance encounter many difficulties regarding language and legal terminology ${ }^{69}$ As empirical research by the European Consumer Centres Network (EEC-Net) on the ESCP application reveals, language requirements and translation are among the most commonly identified difficulties for this instrument. ${ }^{70}$ If a court needs to clarify information, it usually asks the party to complete and/or to rectify the data submitted (Form B). This is done most of the time in the procedural language of the court. In the event the interested party does not understand the language of procedure, this party is left in a situation where he or she either requires legal assistance

\footnotetext{
Ann. I to ESCP.

Ann. III to ESCP.

See also comments on this issue in the 'EOP approach' above.

See also comments on this issue in the 'EOP approach' above.

Art. 25 ESCP.

On standard forms, see Section 3.3.

'Procédure de Règlement des Petits Litiges et Injonction de Payer Européenne', above n. 41, at 6.

European Consumer Center-Net joint Project (2010), 'The European Small Claims Procedure. Outcome of the Survey in the Implementation of the Regulation 861/2007', Working Group: ECC IT, LT, EE, PL, EJN 35th Meeting of the Contact Points, Brussels, May 2011; 'Procédure de Règlement des Petits Litiges et Injonction de Payer Européenne’, above n. 41, at 5; X.E. Kramer and E.A. Ontanu, above n. 49, Section
} 5.1 . 
and translation or drops the procedure. ${ }^{71}$ To remedy this type of situation, courts in the Netherlands sometimes accept forms in a foreign language, provided they are able to read and understand these forms. ${ }^{72}$ However, it is clear that the ESCP forms must contain more concrete guidance for the parties on the language of procedure, even if the courts are flexible and multilingual on their own initiative.

Article 6(3) and Recital 19 ESCP contain provisions on the language of communication with the other party: that is, the language of documents to be served or dispatched. In fact, while the parties should communicate with the court in the language of procedure, communication with the other party is not necessarily done in that language. These provisions seek to guarantee that each party is able to understand the documents served. Article 6(3) together with Recital 19 of the Regulation incorporates the rules contained in Article 8 of the Service Regulation. ${ }^{73}$ Service of documents implies an official procedure and acknowledgment that a document was delivered in a Member State, while dispatch refers to a simple sending of a document.$^{74}$ According to these provisions, the institution serving a document should inform the recipient in writing about possibilities to refuse the document or to send it back to the sender if the document is not translated into the language (or one of the languages) that the recipient understands, or into the official language (or one of the official languages) of the place where service is to be effected (or where it is to be dispatched). In the event of a refusal by the party on which the documents are served (or dispatched), the court is to inform and instruct the other party to provide a translation of the document. ${ }^{75}$ Consequently, in almost all cases, the same form should be established in two languages simultaneously: the language of procedure (to communicate with the court) and the language of the other party (in order to be served to the other party). This happens both when the claimant fills in Forms A and B (rectification of the Form A) and when the defendant fills in Form C.

In addition, in order to secure access to justice, parties should be informed that they may refuse the forms and documents serviced or dispatched, provided these are not in the language or accompanied by a translation in the official language of the place of service or a language they understand.$^{76}$ One published decision by a Dutch court appears to go against the provisions in Article 6(3) of the ESCP Regulation. ${ }^{77}$ It is worth mentioning because to date this is the only published case involving a refusal of the ESCP based on the language used in the form. The claim form and the supporting documents were submitted in Dutch to the court in the Netherlands and then served on the defendant in Latvia. ${ }^{78}$ The Latvian party attempted to refuse the document, invoking as the reason inter alia the language used in the form. Nevertheless, the court dismissed the reasons invoked by the Latvian company and motivated its decision on the basis of the provisions of Article 6(1) of the Regulation, stating that the claim form and the supporting documents were submitted in the language of the court, in conformity with the ESCP. The court ignored in this case the difference between the language of procedure (Article 6(1) and (2)) and the language of service (Article 6(3)). Such approach in the ESCP application results in denying parties an access to justice. Generally, according to research done in the Netherlands, the courts seem to be confused as to what to do with a claim form in Dutch when they need to serve it on a foreign defendant. Courts do not provide a translation of the forms on a normal basis due to the financial burden it would represent. Consequently, in some cases, the answer form is sent to the defendant in the

71 'Procédure de Règlement des Petits Litiges et Injonction de Payer Européenne', above n. 41, at 5.

72 According to Dutch courts, forms or additional materials are often submitted in languages other than Dutch; in a majority of cases, these are English, French, or German. See X.E. Kramer and E.A. Ontanu, above n. 49, Section 5.2.2.

73 This refers to the new Service Regulation, Reg. 1393/2007 repealing Council Reg. 1348/2000.

74 For example, only dispatch is needed for providing the claimant with the copy of the response of the defendant (Art. 5(4) ESCP). See also P.M.M. van der Grinten, 'Europese Ontwikkelingen', 17 Tijdschrift voor Civiele Rechtspleging 1, at 35 (2009).

75 Art. 6(3) ESCP.

76 Art. 6(3) ESCP read in conjunction with Recital 19 ESCP and Art. 8(1) Service Regulation.

77 On this decision, see also X.E. Kramer, 'Small Claim, Simple Recovery? The European Small Claims Procedure and its Implementation in the Member States', 1 ERA Forum 131 (2011).

78 Rechtbank Amsterdam, 30 August 2009, LJN BO2995. 
official language of the defendant's Member State, and a copy of the claim form is sent to the defendant in the language of procedure. ${ }^{79}$ This practice of the courts provides the defendant with some information on the procedure, but this approach may lead to more confusion as to which language is to be used for the response. Of course, rectification of the form is possible ${ }^{80}$ but it is time consuming and implies more costs.

Furthermore, translation costs should be treated as procedural costs. ${ }^{81}$ In our opinion, the ESCP, as a harmonised procedure, would benefit from clearer provisions on the party bearing the costs of translation (in the text of the Regulation and in field 7 of the claim form). In cross-border cases, translation is very often needed, and costs might be significant in relation to the claim.

Finally, Form D is used in order to enforce the ESCP court decision. This form must be translated into the language accepted by the Member State of enforcement ${ }^{82}$ if the language of procedure (and therefore the language in which the court issues Form D) is not one of the languages accepted for enforcement purposes. ${ }^{83}$

To conclude, it is important to note that translation remains necessary in order to secure parties' access to justice in cross-border cases involving the ESCP. The system of forms established by the ESCP Regulation is set to reduce the volume of documents to be translated into the language of procedure or for service and enforcement purposes. Further, not all documents submitted to the court need to be translated into the language of procedure, unless the court considers this necessary for issuing the judgment. For future developments to be considered, it might prove useful if the ESCP Form A (claim form) were to inform the claimant that his or her communication with the defendant should be done in the language of the defendant (ESCP in conjunction with Service Regulation and national rules of the concrete Member State on language). In practice, this will indicate immediately to the parties that the same forms might need to be used in two different languages. As well as informing the defendant that his or her communication with the court should be in the language of procedure, Form $\mathrm{C}$ (answer form) should make clear that the same document might need to be translated in order to correspond to the requirements in Article 6(3). Moreover, parties should be informed clearly that in most cases a translation would be needed for enforcement of the ESCP (Form D) in another Member State, unless the language of procedure corresponds to the language accepted for enforcement. As with the EOP, a step-by-step informing of the parties on the correct language to use appears difficult to implement in a paper-based form. This strategy can be envisaged more easily in a dynamic form in an electronic format to be developed on EU websites. ${ }^{84}$

\subsection{Standard Forms}

Both the EOP and the ESCP rely mainly on standard forms. Two major potential outcomes of conducting litigation in this manner might be envisaged within these European procedures: firstly, it could diminish language obstacles facing parties and courts during the procedure; ${ }^{85}$ secondly, the courts could issue decisions that are easily recognisable in the Member States, and that could circulate freely for enforcement purposes within the EU. These elements would contribute to decreasing language obstacles relating to the enforcement of decisions.

79 X.E. Kramer and E.A. Ontanu, above n. 49, Section 5.2.2.

80 Art. 4(4) ESCP.

81 P.M.M. van der Grinten (2009), above n. 74, at 35.

82 One of the languages reported by the Member States and made public though the official portals that we touched upon in Section 3.1.

83 Art. 21(2)(b) ESCP.

${ }^{84}$ For perspectives on technical solutions, see Section 4.

85 A. Ryng, 'How to Deal With Language Problems in Cross-border Litigation in Civil Matters?', in P. van der Grinten et al. (eds.), Practical Obstacles in Cross Border Litigation : Speeches and Presidency Conclusions of the International Conference Organised by the Dutch Presidency on 8 and 9 November 2004 in The Hague (2005) 5, at 7. 
EOP forms are based on number codes, letter codes corresponding to particular information to be provided for the form, and 'tick box' fields. ESCP forms are based on 'tick box' fields, short closed questions and fields requiring certain information from parties (including contact details and name of the party). The forms are available online in all 23 official languages of the EU ${ }^{86}$ Parties are therefore provided with a possibility to consult a form in their own language in order to fill in the form in a foreign language. In simple terms, a party can download and print out a form in his or her own language along with the same form in a foreign language. A party can then put these forms next to each other, read the question or the name of the field in his or her own language, pick the code with the answer, fill in the codes, tick the 'tick box' fields, and complete the fields requiring contact details of the party, all of this in the form in a foreign language. It is also possible to fill in the form electronically by using the language of the party and then automatically transferring it online ${ }^{87}$ in the requested language of procedure. All this pre-established information is translated automatically, and does not imply any costs for the parties. The number of open questions is limited, but professional translation remains necessary in this case. In the ESCP, translation remains necessary for additional evidentiary documents as well, so the burden does not appear to be much reduced for this situation.

Furthermore, for the purpose of Form G of the EOP and Form D of the ESCP representing the enforceable title, language obstacles should be further diminished. A future solution for diminishing the parties' translation burden would be to allow Member State courts the possibility to issue their decision not only in the language of the court but also in the language accepted by the Member State of enforcement. The use of codes or a 'tick box' system can be handled easily for this purpose. The courts could, in principle, also proceed in the same way as the parties to produce two documents in different languages. As regards the claimant, this approach would dispense with the need to translate the EOP/ESCP decision for its enforcement. Generally, the use of standard forms diminishes the need of translation and has the potential of reducing language obstacles. However, in practice, pre-established text may prove to have very little flexibility in the handling of a case. For instance, some Dutch judges pointed to the rigid character of the ESCP forms. In order to preserve the purpose of the procedure, the courts needed to contact the party in a less formal manner in order to understand the basis of the claim or to assess the arguments of the party. ${ }^{88}$ Considering this aspect, the EOP and ESCP Regulations should perhaps provide parties and courts with standard forms having more flexible content, depending on the circumstances of the case.

\subsection{Oral Hearing and Taking of Evidence}

Language obstacles are diminished through the use of standard forms, even if translation of these forms turns out to be necessary. These translations need to be in written form, hence the translator has more time to reflect upon the text than does the oral interpreter, and can eventually consult experts and look up terms. Moreover, a translator does not have to attend the court hearing, and a written translation is usually less costly than an oral interpretation.

Due to its adversarial nature, the ESCP provides for a possibility to hold an oral hearing, ${ }^{89}$ as well as to take evidence if this is necessary for giving judgment. ${ }^{90}$ Both an oral hearing and the taking of evidence can require an oral interpretation.

A court hearing should be held only if the court considers it necessary or a party requests it. According to information available on the practice of the courts, oral hearings in the ESCP appear to be held only rarely. In the Netherlands, judges try to keep the

\footnotetext{
86 See also Section 3.1 of this article on online information.

$87<$ http://ec.europa.eu/civiljustice/simplif_accelerat_procedures/simplif_accelerat_procedures_ec_ en.htm> (last visited 22 Jun. 2012), <https://e-justice.europa.eu/content_dynamic_forms-155-en.do> (last visited 22 Jun. 2012).

${ }_{88}$ X.E. Kramer and E.A. Ontanu, above n. 49, Section 5.2.2.

89 Art. 5(1), Art. 7(1)(c) and Art. 8 ESCP.

90 Arts. 7(1)(b) and Art. 9 ESCP.
} 
procedure in written form. According to interviews with eight out of the nineteen Dutch courts involved, up to the present, few oral hearings have been held within the ESCP. ${ }^{91}$ There have been only two reported requests for an oral hearing, but in one case the court did not find it necessary in the light of further written information provided by the parties at the request of the court. The courts' opinion is that holding court hearings is contradictory to 'the spirit' of the ESCP, taking into consideration the burden of appearing in court for a party domiciled abroad. ${ }^{92}$ Before deciding on the taking of evidence, the court has to consider related costs, and make use of this mechanism only if it is necessary for giving the judgement. Furthermore, 'simplest and least burdensome methods have to be considered' by the court. ${ }^{93}$ In practice, the taking of evidence does not seem to be a usual approach.

In principle, if parties and/or the judge only understand different languages, an interpretation (oral translation) will be needed both for the oral hearing and for the taking of evidence. This will not diminish the language obstacles. The judges' approach to hold oral hearings and to take evidence only as exceptions to usual practice is in line with the aims of the ESCP to reduce litigation costs and to simplify procedure. This approach does not hinder a fair trial; instead, it represents a solution that protects parties from bearing the costs of translation and of long procedures.

\section{Options for Languages in EOP and ESP Procedures: Perspectives}

As we have seen, translation remains essential to guarantee parties' proper access to justice, and it protects the right to a fair trial in EOP and ESCP procedures. Tools such as standard forms and code/'tick box' systems to a certain extent reduce the need of translations. Their use in practice, put to the test since the EOP and the ESCP entered into force, has the potential to diminish access to justice for parties not familiar with the use of standard forms and codes. Might this mean that there is no other way to diminish the need of translation while safeguarding the right to a fair trial and access to justice?

A hypothetical solution intended to reduce the need for language translation is the use of a single language for EOP or ESCP proceedings. Europeans seem to widely agree that they 'should be able to speak a single common language'. ${ }^{94}$ When asked about languages in the ESCP, some Dutch judges suggested conducting this procedure in English because it is a European procedure; however, this view is certainly not shared unanimously by the courts. ${ }^{95}$ The choice of a single language for cross-border purposes makes the issue more complex. For instance, English is particularly important in commercial EOP and ESCP cases. English is used increasingly in international trade as a lingua franca of communication and contracts, ${ }^{96}$ and is often chosen for practical reasons as a language for communication when the assistance of a foreign lawyer is needed. Litigating any subsequent disputes in another language due to court requirements can generate high translation costs, in particular for documentary evidence. The translation of contractual terms and correspondence between parties can further expose them to possible terminological misunderstandings and, in more extreme situations, to wrong court decisions. ${ }^{97}$ The increased use of English in international trade was remarked upon by certain Member States, such as France and Germany. These countries made it possible or proposed to use English as the language of court procedure

\footnotetext{
X.E. Kramer and E.A. Ontanu, above n. 49, Section 5.2.2.

Id.

3 Arts. 9(2) and (3) ESCP.

"More than four in five of Europeans (84\%) agree, and more than two in five (44\%) "totally agree", that all EU citizens should be able to speak a foreign language', Eurobarometer 386, Europeans and their Languages, at 111 (2012).

95 X.E. Kramer and E.A. Ontanu, above n. 49, Section 5.2.2.

96 G. Cordero Moss, 'Harmonised Contract Clauses in Different Business Cultures', in T. Wilhelmsson et al. (eds.), Private Law and the Many Cultures of Europe (2007) 221, at 221.

97 S. Huber, 'The German Approach to the Globalisation and Harmonisation of Civil Procedure: Balancing National Particularities and International Open-Mindedness', in X.E. Kramer and C.H. van Rhee (eds.), Civil Litigation in a Globalising World (2011) 291, at 297. See also the contribution by C.A. Kern in the current volume.
} 
in certain chambers of their courts ${ }^{98}$ allowing parties to present documentary evidence and plead in English. The decision of the court should, however, be issued in French and, respectively, German. ${ }^{99}$

This means that some Member States at the individual level demonstrate loyalty to a 'choice of language' in commercial litigation, particularly to the choice of English. Thus far, however, this option has only been made available by a few Member States. If a common European decision is made that a EOP and/or a ESCP in commercial cases should be conducted in English (as a single language of procedure), safeguards for the right to a fair trial and access to justice should be provided. It would require verification that the choice of language is made explicitly. In addition, assessment of the quality of English used by the parties in the documents (possible grammatical or lexical mistakes and lack of familiarity with legal terms resulting in ambiguities or mistakes in understanding), and an assessment of parties' understanding of English will also be a responsibility of the court. Fulfilling any of these tasks appears problematic because English will most probably be a foreign language for both the judge and at least one of the parties. Furthermore, it requires time and additional costs, and represents special tasks outside the usual scope of the judge's function. Finally, the burden of assessing even the judge's level of English should not be neglected. In this perspective, a party should be provided with a possibility to challenge the court's decision if there are serious reasons to acknowledge that the language skills of the court were not sufficient or adequate when the decision was taken. For these reasons, the exclusive use of English for a EOP and a ESCP in commercial cases does not seem to be a solution. Also, while the EOP is relevant for both commercial cases and for litigation involving consumers, the ESCP is primarily relevant for cases where one of the parties is a consumer.

Unlike for commercial transactions, English is not a lingua franca in situations involving consumers. ${ }^{100}$ For example, many Internet sites are usually available in several languages, and consumers have the opportunity to conclude transactions in their own national language. However, not all sites have pages available in all official EU languages. If no communication or purchasing in one's own national language is possible, it is often English that is used for communication or selling on the Internet. ${ }^{101}$ Even if consumers buy in English, buying goods in a foreign language is a poor reason to conclude that parties had voluntarily chosen the language of purchase. It is also a poor reason to consider that parties made a 'choice of language' in the same way as for commercial transactions. Consumers do not have the same negotiating power as professionals in concluding contracts. Furthermore, the level of knowledge of foreign languages remains modest amongst Europeans on the whole. ${ }^{102}$ It would therefore be unreasonable if the EOP and the ESCP were to allow the language on which a purchase has been made by a consumer to become a single language of procedure and/or the single language of communication between parties. Furthermore, as to a possibility for European consumers to litigate cross-border in one single language, a comparison can be made with communication between the EU institutions and the citizens. The option of using a single language for this purpose has been rejected as not being sufficient, ${ }^{103}$ as contradicting the very idea of multilingualism, and as diminishing the recognised value

\footnotetext{
98 In France, the Commercial Court of Paris allows proceedings in English, Spanish, and German. This approach is adopted by certain Member States in order to make their litigation system more attractive to international trade, thus seeking to avoid a clash between the language of the contract and the language of the proceedings. See S. Huber, above n. 97, at 296. 99 Id.

100 'At a national level, English is the most widely spoken foreign language in 19 of the 25 Member States where it is not an official language (i.e. excluding the UK and Ireland)', Eurobarometer 386, Europeans and their Languages, at 6 (2012).

101 For example, Internet pages of European air carriers Lufthansa and Czech Airlines offer no possibility to buy tickets in Finnish, Greek, Dutch, or Estonian, and offer only English pages as an alternative.

102 ' $44 \%$ of Europeans say that they are able to understand at least one foreign language well enough to be able to follow the news on radio or television', Eurobarometer 386, Europeans and their Languages, at 6 (2012).

${ }_{103}$ K. Krzeminski et al., 'Practical Obstacles in Cross-Border Litigation. Conference report', 54 Ars Aequi $206(2005)$.
} 
of language diversity. ${ }^{104}$ Therefore, replacing the solution of translation into parties' own languages by the use of one single language is currently not realistic for cases involving consumers.

A possible temporary solution proposed by the European Consumer Centre Ireland (ECC Ireland) in practice ${ }^{105}$ is to require Member States to accept written documentations and forms in at least the most widely known languages across the European Union (i.e. English, French, and German). ${ }^{106}$ In our opinion - and in order to guarantee the procedural rights of access to justice and a fair trial that we have mentioned with regard to the use of English as a single language - this option raises the same questions of assessment of the level of the language skills both of the judges and of the parties.

The question of translation should focus instead on the kind of translation to which the EOP and the ESCP should strive. A fully automated translation (or computer-aided translation) seems to be the most realistic option. In this case, involved parties are not required to know a foreign language, and information relevant for the procedure can potentially be presented automatically in the language of the interested party.

The European Commission maintains a keen interest in the possibilities of using new information and communication technologies in order to facilitate parties' access to courts in cross-border cases. ${ }^{107}$ Steps have been taken in this direction by providing electronic standardised forms whose template can be automatically translated following a draft filled in by the interested party. However, at present, additional information by the parties cannot be automatically converted to a different language. Automatic translation of the forms' entire content is the next objective to achieve. ${ }^{108}$ The EOP and the ESCP would rely on dynamic forms with predetermined text and legal terminology in order to obtain a quick conversion of the text into any necessary language according to national procedural requirements. ${ }^{109}$ The Stockholm Programme in 2010 envisaged information technology solutions that could be incorporated in the process of generating the forms. The platform used for this purposes, the e-Justice portal, is conceived as an information instrument, providing all the necessary data on justice systems. ${ }^{110}$ As has been announced by the European Commission, the e-Justice is meant to be a response to the 'threefold need to improve access to justice, cooperation between legal authorities,

\footnotetext{
104 Art. 167 TFEU declares the value of the linguistic diversity and the right of petition in any language is considered to be included in the Art. 41 of the Charter of Fundamental Rights of the EU.

${ }_{105}$ European Small Claims Procedure. First Year of Operation in Ireland, European Consumer Centre Ireland, November 2010, <www.eccireland.ie/downloads/ESCP.pdf $>$ (last visited 22 Jun. 2012), at 20.

106 See the Communication from the European Commission to the Council, the European Parliament, the European Economic and Social Committee and the Committee of the Regions - A New Framework Strategy for Multilingualism, COM (2005) 5996 final, Brussels, 22.11.2005, not published in the Official Journal of the European Union, <http://eurlex.europa.eu/smartapi/cgi/sga_doc?smartapi!celexplus!prod!D ocNumber\&lg=en\&type_doc=COMfinal\&an_doc $=2005 \& n u \_d o c=596>$ (last visited 1 May 2012), at 1617.

107 See for example $<\mathrm{http} / /$ ec.europa.eu/justice home/judicialatlascivil/html/index_en.htm $>$ and $<\mathrm{http}: / /$ ec.europa.eu/civiljustice/simplif_accelerat_procedures/simplif_accelerat_procedures_gen_en.htm $>$ (last visited 22 Jun. 2012).

108 See Communication from the Commission to the Council, the European Parliament and the European Economic and Social Committee - Towards a European e-Justice Strategy, Brussels, COM (2008) 329 final, $<\mathrm{http}$ ://ec.europa.eu/civiljustice/docs/com_2008_329_en.pdf $>$ (last visited 22 Jun. 2012), at 10; European Small Claims Procedure. First Year of Operation in Ireland, above n. 105, at 20.

109 Council Note 15315/08 point 43: 'One specific solution to this linguistic challenge could be to use automated translation systems, particularly for the content of forms used in European instruments, and to place national translation resources online' and point 44 'a working method needs devising which ensures faithful translation, in the European Community's twenty-three official languages, of the legal concepts which exist within Member States' legal systems, taking into consideration questions relating to semantics', $<$ http://register.consilium.europa.eu/pdf/en/08/st15/st15315.en08.pdf $>$ (last visited 1 May 2012).

110 The e-Justice webpage (e-justice.europa.eu) provides citizens with information on law, case law, judicial systems, legal professions and justice networks, cross-border legal proceedings, legal aid, mediation, successions, wills, victims' rights in case of criminal offences, videoconferencing, cooperation on civil and criminal matters, business and land registers, finding a lawyer, translator/interpreter, notary public or mediator, and online dynamic forms for the European Regulations, where procedures are based on standard forms.
} 
and the effectiveness of the justice system itself' ${ }^{111}$ The next step for EOP and ESCP forms will be in the development of dynamic online forms that could automatically generate the necessary language translations accepted by the competent court. ${ }^{112}$ In addition, a full electronic application for a ESCP on the e-Justice portal is envisaged by the European Commission, which intends to launch a feasibility study for this purpose. ${ }^{113}$

It is true that no perfect automated translation exists so far; ${ }^{114}$ machines cannot translate in the same way that humans can. However, the history of translation in general is developing towards the use of automated tools. Automatic dictionaries, databases and, finally, translators' programs have been created. Programmes memorising complete patterns and managing special vocabulary on an automated basis have been developed. ${ }^{115}$ To simplify cross-border litigation, the role of humans (judges, translators and others) should rise with the increase in complexity of litigation or the amount of claim, but decrease when a simpler approach is appropriate. Automated translation seems to be a realistic way to reduce language obstacles in civil procedures. This can lead to an improvement in the EOP and ESCP standard-form solution, delivering results that are more user friendly and less expensive than translation, and thus diminishing the burden of cross-border litigation.

\section{Concluding Remarks}

The provisions of the two autonomous European procedures analysed in this article strive to establish a balance between parties' rights to a fair trial and access to justice and the purpose of these procedures: namely, to simplify cross-border litigation and to diminish its costs. The introduction of standard forms and their online availability in all official languages will contribute to reduce language obstacles.

However, in practice there are still barriers to overcome regarding available information and assistance in filling in a form in the national language or in a foreign language. This has been confirmed by empirical research available to date. An analysis of EOP- and ESCP-related information available on the official websites of both the Commission and Member States shows that more transparency and accuracy of data are desirable. The information should also be presented in a form easily accessible not only for a lawyer but also for a layperson.

Furthermore, the EOP and the ESCP imply special rules on the use of languages, with the ESCP containing express provisions on language, and the EOP relying implicitly on rules established by the Service Regulation. The EOP is therefore less clear on language use, and it is desirable that future reviews include clarifications on this issue. Moreover, in the text of both Regulations a differentiation is desirable between the language of procedure of the court, on the one hand, and the language of service or dispatch of documents to the other party, on the other hand. As a matter of fact, in nearly all cases, the same form should be established in two languages simultaneously: that of procedure

\footnotetext{
111 Communication from the Commission to the Council, the European Parliament and the European Economic and Social Committee - Towards a European e-Justice Strategy, above n. 108, at 2.

112 The ECC Ireland considers in its report that the European Commission and the Member States 'should provide for programmes supporting professional and automatic translation to facilitate the exchange of information'. See European Small Claims Procedure. First Year of Operation in Ireland, above n. 105, at 20 .

${ }_{113}$ Council of the European Union, 'Implementation of the European e-Justice action plan - Roadmap', of 21 May 2010, 9714/1/10, <http://register.consilium.europa.eu/pdf/en/10/st09/st09714-re01.en10.pdf > (last visited 1 May 2012), at 4.

114 For limitations of computer technology in translation, see K. Malmkjaer and K. Windle (eds.), The Oxford Handbook of Translation Studies (2011), part VI.

${ }_{115}$ See inter alia K. Malmkjaer and K. Windle (eds.), The Oxford Handbook of Translation Studies (2011); A. Alcina, 'Translation Technologies: Scope, Tools and Resources', 20 Target: International Journal On Translation Studies 79 (2008); L. Bowker, Computer-Aided Translation Technology: A Practical Introduction (2008); M. O'Hagan and D. Ashworth, Translation-Mediated Communication in a Digital World: Facing the Challenges (2002).
} 
(to communicate with the court) and that of the other party (in order to be served to the other party). This is the case for the applicant filling in the forms as well as for the claimant.

In our view, both Regulations should contain provisions that (a) any document to be sent to the court should be established in or translated into the language of procedure of the court, and (b) any document to be served should either be established into the language that the defendant understands or into an official language of the Member State where the service should be effected, or translated into one of these languages. In addition, each Regulation should identify the party that bears the costs of translation.

We consider it desirable that both EOP and ESCP forms provide a reference to the concrete language of the procedure to be used by the party in communication with the court, depending on the concrete court where the party intends to file the claim. This reference might help limit confusion resulting from language issues and reduce cases where the court needs to ask for rectification of information. Since the same form should often be used simultaneously in the language of procedure and translated into the language of service, an additional field pertaining to eventual translation costs would be appropriate both in the EOP and the ESCP application/claim forms. Therefore, the EOP and ESCP approach to language issues still needs to be improved.

An element that has proven very useful in practice is the availability of legal assistance for parties interested in using a EOP and a ESCP for cross-border litigation; future reviews of these Regulations should improve this mechanism, thus allowing easier access to justice. De lege ferenda, this should be made available within the EOP procedure as well. Furthermore, national bodies offering this type of assistance within the EOP and the ESCP should be clearly individualised within the Member States, in order for interested parties to have easy access to information.

The use of standard forms is an important step forward in cross-border litigation within the EU. Further developments can be achieved by establishing dynamic interactive forms on European websites: namely, forms that adapt their structure to details of the case, and that offer the flexibility needed by courts in handling the cases. 